\title{
Talent Promotion Programs and Management of Formal Education in Nigeria
}

\author{
Nimota Jibola Kadir Abdullahi and Seun Muyiwa Sotayo
}

\begin{abstract}
This study examined talent promotion programs and management of formal education among youth in Nigeria. This quantitative study determined the perception of administrators and lecturers on the importance of personality development, sports, music and reality television shows towards effective management of formal education. A purposive sampling technique was used to select 45 participants in three departments at the University of Ilorin, Kwara State, Nigeria. Data was collected using a Talent Promotion Programs and Management of Formal Education Questionnaire (TPPMFEQ), and analyzed using descriptive statistics. The findings revealed that personality development, sports, music and reality television shows are important towards effective management of formal education. The findings indicate that the government should promote personality development of youth by upgrading the monetary value given to high achievers in school after completion of their programs or degree in order to spur more interest in appreciating education and shaping the behaviour of individuals. Also, the government should provide sportsacademic scholarship schemes that would serve as criteria and support for talented youth in order to assist them in pursuing their dreams and ensuring that all citizens are catered for educationally. In addition, the government should also place more emphasis on music as a way of bringing about a better life for youth. As well, the government should ensure the effective regulation of television programs so that they are educative, meaningful and relevant to the progress of youth in order to empower and reduce the problem of unemployment and poverty among youth.
\end{abstract}

Keywords: talent, program, youth, formal education, Nigeria

Dr. Nimota Jibola Kadir Abdullahi began her professional career as a secondary school teacher and currently works as a lecturer in the Department of Educational Management at the University of Ilorin, since 2015 and her lines of research include: educational administration and planning, management, ICTs, economics of education and human resources. She has published different papers in journals of an international nature of the aforementioned areas. Recent publications include: Abdullahi, N. J. K., Tijani, A. A. \& Sofoluwe, A. O. (2020). Visionary leadership and staff innovative behaviour in public colleges of education in Kwara State, Nigeria. International Journal of Education, 12(2), 63-76. DOI: 
https://doi.org/10.17509/ije.v1212.18998; Abdullahi, N. J. K., Tijani, A. A., \& Musa, R.M. (2020). Managing quality assurance process for the attainment of educational objectives in secondary schools in Nigeria. Proceeding on Engineering Sciences (Scopus index). 2(1), 21-30. DOI: www.pesjournal.net.10.24874/PES02.01.003; Abdullahi, N. J. K. (2020). Instructional media and management of elementary schools education in Kwara State Nigeria. Indonesian Journal of Elementary Teachers Education (IJETE) 1(1), 9-26. https://journal.uniku.ac.id/index.php/ijete; Abdullahi, N. J. K. (2020). Social transformation issues and management of educational goals achievement in Nigeria. International Journal of Learning and Teaching (IJLT), 2(2), 100-114 DOI: http://doi.org/10.18844/ijlt.v12i2.4597; Abdullahi, N. J. K. (2020). Raising awareness of climate change issues in Nigeria through education for policy and practice. Journal of Research, Policy and Practice of Teachers and Teacher Education (JRPPTTE), 10(1), 14-26. http://ejournal. Upsi.edu.my/; Abdullahi, N. J. K. (2020). Managing teaching approach in early childhood care education towards skill development in Nigeria. Southeast Asia Early Childhood Journal (SAEC), 9(1), 59-74. http://ejournal.upsi.edu.my/index.php/SAEC; Abdullahi, N. J. K. (2020). Ethical leadership and staff innovative behaviour in Nigeria. Journal of Social Sciences and Humanities, 59(1), 1-19. http://doi.org/10.46568/jssh.v59i1.322; Abdullahi, N. J. K. (2020). Human resource development and management of tertiary education for global competitiveness in Nigeria. Journal of Arts and Social Sciences, 7(1), 75-88. http://ojs.jass.pk/ojs/index.php/jass/isssue/corrent; Abdullahi, N. J. K. (2020). Educational leadership behaviour and community engagement in Kwara State, Nigeria. Educational Leader (Pemimpin Pendidikan), 8(1), 45-62. https://ejournal.um.edu.my/index.-php/ PEMIMPIN/issue/current and Abdullahi, N. J. K. (2020). Quality assurance and management of basic education improvement in North central, Nigeria. Proceeding on Engineering Sciences (Scopus index). 2(3), 333-344. DOI: www.pesjournal.net.10.24874/PES02.03.012

Seun Muyiwa Sotayo is a final year student in the department of Educational Management, Faculty of Education, University of Ilorin, Kwara State, Nigeria. 


\section{Introduction}

Talent promotion programs aid the development and nurturing of innate skills and talents of individuals in various fields of life. The development of talent cannot be possible without first identifying individuals with potential and latent skills waiting to be mentored and directed to help achieve maximum results. Formal education is the greatest and most reliable weapon required to fight against poverty and underdevelopment. Education is a tool necessary to drive national development. This means that a country cannot grow above its educational system. Education is closely related to civilization, and progress and it has the capacity to shape human life.

However, many Nigerian youths today pay less attention to formal education due to the high rate of unemployment in the country, thereby resorting to other avenues to actualize their dreams and become successful. Many Nigerian youths now prefer to pursue a career in the entertainment industry as well as sports in order to satisfy their numerous wants and desires. In 2017, the best graduating student of the University of Nigeria, Nsukka, who graduated with a CGPA of 4.94 was awarded a sum of N10,000 (Ten thousand naira) as the best graduating student of the university. (https://everyday.ng/2017/08/12/chidimma-the-story-of-unn-best-graduatingstudent-that-got-n10000-award/). In addition to this, the University of Ilorin's best graduating student in 2016 was awarded a sum of N20,000 and N10,000 respectively from the school senate and the faculty of clinical sciences for her ground-breaking feat academically taking ten out of twelve awards home.

This development met a lot of criticism online as Nigerians shared their opinions on the relevance that Reality TV shows and entertainment enjoy in place of education and the financial gains behind these talent promotion programs in which the duration is mostly between eight to twelve weeks. Sporting activities, especially football, is prominent in Nigeria and very profitable in European countries where footballers are paid handsomely compared to someone who is educated up to tertiary level. Going by this, there has been a problem with drop-outs and evasion from tertiary institutions by young people who see entertainment as a way out of poverty and fulfilling their dreams at the expense of education. These and many other related issues prompted the researchers to investigate the talent promotion programs and the management of formal education in Nigeria.

\section{Purpose of the Study}

1. To examine the relationship between personality development and management of formal education.

2. To investigate the relationship between sports and management of formal education.

3. To find out the relationship between music and management of formal education.

4. To determine the relationship between reality TV shows and management of formal education. 


\section{Research Hypothesis}

$\mathrm{H}_{01}$ : There is no significant difference between the mean score of administrators and lecturers on personality development and formal education.

$\mathrm{H}_{02}$ : There is no significant difference between the mean score of administrators and lecturers on sports and formal education.

$\mathrm{H}_{03}$ : There is no significant difference between the mean score of administrators and lecturers on music and formal education.

$\mathrm{H}_{04}$ : There is no significant difference between the mean score of administrators and lecturers on reality Television shows and formal education.

\section{Review of Related Literature}

\section{Talent Promotion Programs}

The talent promotion program is an expanding field of enquiry in sports, and music globally. Talent promotion programs aid the development and nurturing of the innate skills of individuals in various fields of life. Talent identification refers to recognizing an individual's abilities or potential within a specific domain. On the other hand, talent development is the provision of quality learning and practice conditions that facilitate the fulfillment of potential (Williams and Reilly, 2000). Talent identification (TI) refers to the process of recognizing current athletes with potential for attaining expert performance (Vaeyens, Lenoir, Williams, Philippaerts, 2008). Talent development (TD), on the other hand, means developing athletes into world-class performers through a series of intervention programs such as physical training. It is of great importance to note that talent development would be more effective in a conducive environment where the skills of talented individuals are harnessed optimally.

The development of talent can be integrated into the school system in Nigeria's tertiary institution to harness the raw talent of individuals. It gives them an option aside from education while still being educated through the provision of resources required for the training of students to achieve their desired goals, and recruitment of skilled and qualified coaches for the achievement of both curricula and co-curricular activities in the school system. To pursue excellence in sport, many sport organizations have either initiated and/or adopted TI/TD schemes (Abbott \& Collins, 2004; Baker \&Schorer, 2010) while developing athletes into elite performers may be attributed to TI programs (Vaeyens, Gullich, Warr, \& Philippaerts, 2009; Wolstencroft, 2002). 


\section{Personality Development and Formal Education}

According to Parkinson (2002), personality is a stem that predicts individual behaviour over a range of situations as well as distinguishes one person in meaningful ways from other people. Research shows that personality traits are at least as important as cognitive skills in determining social outcomes such as criminal behavior and marital stability, together with health and mortality (Heckman et al, 2013; Roberts et al, 2007; Piatek \& Pinger, 2010; Duckworth \& Seligman,2005).

\section{Sports and Formal Education}

Sports are the various activities which individuals engage in from childhood to adulthood which promotes the acquisition of mental, physical, spiritual, aesthetic, emotional and educational well-being to make the individual contribute meaningfully to the development of society (Darling, Caldwell \& Smith, 2005). Sports are divided into the following categories: athletics, gymnastics, individual/dual sport, team sports, rhythms dance, martial arts, and combative sports. There are other types of sports including football and volleyball. Specifically, one of the aforementioned types of sports that is of relevance to this research is the impact of football on youths and education.

The following are the objectives of sports: physical fitness, social efficiency, skill acquisition, emotional stability, life career, cultural development and mental development (Hannah, 2015). Sports and education are seriously interwoven as one promotes the other. One is also embedded in the other as sports form parts of education, so education also provides a forum by which different aspects of sports manifest its practices and activities. Marsh and Kleitman (2002) found that student-athletes' participation was of value to students. In their study, Marsh and Kleitman examined the effects of extracurricular school activities on high school and postsecondary outcomes. More specifically, their research endorses that students' participation levels increases their academic achievement. However, Marsh and Kleitman also found that in high levels of involvement, a student would begin to see a drop in their academic achievement. This means that there were positive results to those who don't really have or have moderate participation, but this positive connection leveled off and then began to drop as students' participation levels continued to rise. Participation in structured athletic activities is also said to promote a wide range of "social, physical, and intellectual skills," leading to better classroom performance (Eccles, Barber, Stone, \& Hunt, 2003).

\section{Music and Formal Education}

Music is a universal language, known and understood in every culture of the world; the fact that its manifestation in the various cultures of the world undergoes some environmental influences notwithstanding (Mereni, 2007). The ultimate purpose of music is for enjoyment of the 
individual, the social group or the community, in a variety of contexts in the home and public places, in work situation, in creation, or on social ceremonial and ritual occasions (Adeola \& Isaac, 2018). Music is a phenomenon linked to mental process, emotions and psychological arousal.

According to Onikoyi (2009), right from the early 60's in Nigeria, music has been a veritable tool of transformation by musicians like Fela Anikulapo Kuti, Ebenezer Obey, Sunny Ade, Oliver d' Coque, Victor Uwaifo, Bala Miller to mention but a few. Music was used by these musicians to correct erring members of Nigerian society including the government. The lyrics of their songs were targeted at warning, instructing, and praising people. This means that music has a moral undertone for its listeners.

However today, many youths see music as a panacea to poverty even when there is clearly a lack of skill in composition of lyrical content as well as artistry capacity. For example, some musical artistes in Nigeria release songs that have no positive impact on the listeners but rather a promotion of nudity and immoral acts as well as substance use among youths. Musicians in Nigeria believe this kind of music appeals to the perception as well as the demands of the media users and is a win-win situation since one of their motives is to increase popularity and financial status. There is a need to bridge this gap with qualitative music education in order to bring about desired reformation in the way music is performed, produced and consumed (Adeola \& Isaac, 2018). Music education is not only concerned with developing musical skill and creativity in the present but also it teaches students how to continue developing their musicianship in the future. Music education extends the range of people's expressive and impressive powers by providing them with opportunities to formulate musical expressions of emotions, musical representations of people, places and things, and musical expressions of cultural-ideological meanings (Darling, Caldwell \& Smith, 2005).

\section{Reality Television Shows and Formal Education}

Television gives a consent picture of what exists, what is important, what is related to peoples' lives, and what is right (Griffin, 2008). In today's society, coupled with the growing use of the internet, media is omnipresent which make its influence even greater. In Nigeria for example, some of the reality television shows broadcast on our airwaves (television specifically) include the controversial Big Brother Naija, MTN Project Fame, Nigerian idol, and Maltina Dance All amongst others. All have, in one capacity or another, influenced youths both positively and negatively. Arguably, some of these talent promotion programs organize auditions to identify raw talents that are capable of developing their full potential. It is also an avenue to change the financial status of the contestants selected, as most youth see this medium as a way out of poverty. This was the view of Papacharissi and Mendelsen (2007) who argued that the premise of reality television requires that individuals place themselves on public display, thus forfeiting all claims to personal 
privacy for the sake of transient fame and the possibility of monetary compensation. This has created a legal ground for youths to substitute formal education for talent promotion programs in order to achieve notable financial status.

Reality television shows contain messages about substance use, dating behaviors, sexual behaviors, gender roles, self-image, and finances, many of which are messages that may be contradictory or mixed. However, as often seen in reality television, these messages do not emphasize negative consequences, but rather seem to reward the characters in the television programming with fame or recognition (i.e. celebrity). L'engle, Brown, and Kenneavy (2006) indicated that the majority of sexual content in the media portrays consequence-free and promiscuous sexual behaviour between non-married people. Media users (mostly adolescents and youths) are more likely to adopt behaviors depicted by characters who are perceived as attractive and realistic and who are not punished, but rewarded, for their behaviour. Interestingly, in Leone's (2006) study, college students were found to view reality television programs as harmful media material, likened to television violence or pornography.

It is noteworthy for the government to censor reality television programs. All forms of immoral and sexual acts depicting real time broadcast should also be discouraged and banned on live television because the effects have negatively affected youth. It has eroded the values of the society as well as morals of the youth. If the nation still holds her future (youths) dear, issues relating to the demoralization and eroding of cultural values of the society must be looked into, including reality television.

\section{Methodology}

\section{Research Design}

Research design is the arrangement of the conditions needed for collection and analysis of data in a manner that aims to combine relevance to the research purpose. A quantitative research design was adopted in this study because of the dual opportunities it presented: 1) examining the relationships that exist between talent development programs and formal education; and 2) being able to acquire the opinion of the sample population, using suitable analysis techniques to analyze the data collected in order to reach a reasonable conclusion from the findings of the study (Ary et al. 2018; Creswell \& Creswell, 2017).

\section{Population, Sample and Sampling Techniques}

The population comprised 45 lecturers and administrators in three selected departments; Performing Arts, Human Kinetics and Psychology at the University of Ilorin, Ilorin, Kwara State. The populace was selected using simple random sampling technique. A purposeful sampling technique was used to select 45 participants from the sample departments. The three departments were selected because the researchers were working in the area related to their discipline. Also, the choice of the participants by the researchers ensured a provision of unbiased information that will help the researchers acquire a suitable conclusion. A stratified random sampling technique 
was used to select lecturers from the sample university departments in order to ensure that all categories of lecturers were given equal opportunity of being selected. Ethics approval was received from each department.

\section{Research Instrument}

The instrument used to collect data for this study was a self-constructed questionnaire. The questionnaire titled "Talent Promotion Programs and Management of Formal Education Questionnaire" (TPPMFEQ) was used to elicit information from the participants of the selected departments. The instrument was also divided into two sections "A and B". Section "A" comprises personal information of the respondents while section "B" (sub-divided into four sections) contains (1) information on personality development and formal education; (2) items on sports and formal education; (3) items on music and formal education; and (4) items on reality television show and formal education. Each sub-section had five questions relevant to the study. The questionnaire used was designed using a Likert four-point rating scale. Participants responded to the four-point Likert scale (4= strongly agree; $3=$ agree; 2 disagree; $1=$ strongly disagree). The criterion mean is given thus: $4+3+2+1 / 4=2.50$. The criterion mean depicts that any item that is above or equal to the criterion mean value of 2.50 is agreed while the one below the criterion mean value is disagreed by the respondent. Punch (2005) concluded that a 4-point Likert scale answer format was completed faster than 5 and 7-point scales.

\section{Validity and Reliability of Instrument}

To ensure the face and content validity of the instrument, draft copies of the instruments were given to three experts in educational management and three experts in measurement and evaluation. Relevant corrections and adjustment were made based on their observations and recommendations. Also, 15 corrected copies were further administered to lecturers who were part of the sample to examine their clearness of the items with regard to wording, instructions and understandability of the scales and questions in order to detect if there are any difficulties that may arise in filling out the questionnaire. Some suggestions that were made were amended properly before the sending out the final copies. To test the reliability of the items, Cronbach's alpha test was used. As shown in Table 1, the value for Cronbach's alpha for this study was proven to be acceptable and reliable. 
Table 1. Reliability Test for (TPDMFEQ)

\begin{tabular}{lcll}
\hline Variables & N & $\begin{array}{l}\text { Cronbach's } \\
\text { Alpha }\end{array}$ & Decision \\
\hline Personal Development & 5 & 0.82 & All items are acceptable and reliable \\
Sports & 5 & 0.84 & All items are acceptable and reliable \\
Music & 5 & 0.80 & All items are acceptable and reliable \\
Reality Television Shows & 5 & 0.83 & All items are acceptable and reliable \\
\hline
\end{tabular}

Table 1 shows that there are 5 items under personal development of talent promotion programs with Cronbach's Alpha of 0.82. Also, there are 5 items under football career with Cronbach's Alpha of 0.84, 5 items under music with Cronbach's Alpha of 0.80 and 5 items under reality television shows with Cronbach's Alpha of 0.83 . Values above 0.70 are considered reliable and acceptable and values above .8 are better and represent a good reliability (Bond \& Fox, 2015; Brannen, 2017). Therefore, the Cronbach's Alpha value for all the 4 indicators of talent promotion programs were around 0.82 . Therefore, the values show a very good internal consistency reliability for scale and all the 20 items in the questionnaire are found to be reliable and acceptable.

\section{Procedure for Data Collection}

The data were collected from the participants using the questionnaire. The questionnaire was distributed to participants with the help of two trained research assistants. These participants were contacted in their respective offices to discuss the objectives of the research and instructions before the distribution of the questionnaire in order to guarantee optimal response rate. The exercise of data collection was smoothly completed within two weeks since the questionnaire was personally administered by the researcher, trained research assistants and with the help of colleagues in the three departments.

\section{Data Analysis}

Descriptive and inferential statistics were used to analyze the data collected. The mean and standard deviation were used to address the research objectives while t-test was used to test the research hypotheses. The t-critical value was compared to the significant level 0.05 , to determine the rejection or the acceptance of the hypotheses.

\section{Findings}

This section discusses the result of the findings. The findings were organized based on research purposes. 


\section{Objective 1: To examine the relationship between personality development and management of formal education}

Table 2: Results showing Personality Development and Management of Formal Education

Responses on Personality Development

\begin{tabular}{|c|c|c|c|c|c|c|}
\hline $\mathbf{S} / \mathbf{N}$ & Personality Development & \multicolumn{2}{|c|}{$\begin{array}{l}\text { Administrators' } \\
\text { Responses }\end{array}$} & \multicolumn{2}{|c|}{$\begin{array}{l}\text { lecturers' } \\
\text { Responses }\end{array}$} & Decision \\
\hline 1 & $\begin{array}{l}\text { Personality development shapes the } \\
\text { behaviour of individuals. }\end{array}$ & 2.93 & 0.966 & 2.95 & 0.966 & Agreed \\
\hline 2 & $\begin{array}{l}\text { Personality development improves } \\
\text { educational success of youth. }\end{array}$ & 2.87 & 0.924 & 2.89 & 0.956 & Agreed \\
\hline 3 & $\begin{array}{l}\text { Fashion programs and various cultural } \\
\text { events like Valentine's day, Friendship } \\
\text { day, and Mothers' day improve } \\
\text { undergraduate's education. }\end{array}$ & 2.93 & 0.914 & 2.80 & 0.982 & Agreed \\
\hline 4 & $\begin{array}{l}\text { Personality development promotes good } \\
\text { morale of youth. }\end{array}$ & 2.82 & 1.014 & 2.77 & 1.047 & Agreed \\
\hline 5 & $\begin{array}{l}\text { Personality development contributes to } \\
\text { social dominance among youth. }\end{array}$ & 2.90 & 0.952 & 2.92 & 1.032 & Agreed \\
\hline & Grand Mean & 2.89 & 0.954 & 2.87 & 0.997 & \\
\hline
\end{tabular}

As shown in Table 2, the overall perception of the administrators and lecturers on the impact of personality development towards enhancing effective management of formal education was interpreted as 'Agreed' (Mean $=2.89, \mathrm{SD}=0.954$ ) and (Mean $=2.87, \mathrm{SD}=0.997)$. This shows that the participants agreed that personality development improves effective management of formal education in Nigeria. Furthermore, all the responses obtained mean values higher than the criterion mean value of 2.50. This shows that the administrators and lecturers agreed that personality development: 1) shapes the behaviour of individuals (Mean $=2.93, \mathrm{SD}=0.966$ ) and (Mean $=2.87, \mathrm{SD}=0.997) ; 2$ ) improves the educational success of youth (Mean $=2.87, \mathrm{SD}=$ $0.924)$ and $($ Mean $=2.89, \mathrm{SD}=0.956) ; 3$ ) that fashion programs and various cultural events like Valentine's day, Friendship day and Mothers' day improves undergraduate's education (Mean = $2.93, \mathrm{SD}=0.914)$ and $($ Mean $=2.80, \mathrm{SD}=0.982) ; 4)$ promotes good morale of youth (Mean $=2.82$, $\mathrm{SD}=1.014)$ and $(\mathrm{Mean}=2.77, \mathrm{SD}=1.047)$; and 5$)$ contributes to social dominance among youth $($ Mean $=2.90, \mathrm{SD}=0.952)$ and $($ Mean $=2.92, \mathrm{SD}=1.032)$.

Objective 2: To investigate the relationship between sports and management of formal education. 
Table 3

Responses on Sports

\begin{tabular}{|c|c|c|c|c|c|c|}
\hline $\mathbf{S} / \mathbf{N}$ & Sports & \multicolumn{2}{|c|}{$\begin{array}{l}\text { Administrators' } \\
\text { Responses }\end{array}$} & \multicolumn{2}{|c|}{$\begin{array}{l}\text { lecturers' } \\
\text { Responses }\end{array}$} & Decision \\
\hline 6 & $\begin{array}{l}\text { Provision of sports- academic scholarship } \\
\text { to improve effective management of } \\
\text { formal education. }\end{array}$ & 2. 84 & 0.984 & 2.88 & 0.995 & Agreed \\
\hline 7 & $\begin{array}{l}\text { sports related activities improve youth } \\
\text { education. }\end{array}$ & 2.81 & 1.033 & 2.86 & 1.005 & Agreed \\
\hline 8 & $\begin{array}{l}\text { Sports activities improve the brain } \\
\text { activity of youth and aids effective } \\
\text { learning. }\end{array}$ & 2.98 & 0.226 & 2.92 & 1.039 & Agreed \\
\hline 9 & $\begin{array}{l}\text { Sports activities promotes healthy youths in } \\
\text { the society. }\end{array}$ & 2.87 & 0.980 & 2.94 & 0.972 & Agreed \\
\hline 10 & $\begin{array}{l}\text { Sports promote a wide range of social, } \\
\text { physical and intellectual skills of youth. }\end{array}$ & 2.81 & 0.965 & 2.98 & 0.228 & Agreed \\
\hline & Grand Mean & 2.86 & 0.838 & 2.92 & 0.847 & \\
\hline
\end{tabular}

As shown in Table 3, the overall perception of the administrators and lecturers on the importance of sports towards enhancing effective management of formal education is interpreted as 'Agreed' (Mean $=2.86, \mathrm{SD}=0.838)$ and $($ Mean $=2.92, \mathrm{SD}=0.847)$. This shows that the participants agreed that sports improve effective management of formal education in Nigeria. Furthermore, all the responses obtained mean values higher than the criterion mean value of 2.50. This shows that the administrators and lecturers agree that sports: 1) improves effective management of formal education $($ Mean $=2.84, \mathrm{SD}=0.984)$ and $($ Mean $=2.88, \mathrm{SD}=0.995) ; 2$ ) improves youth education (Mean $=2.81, \mathrm{SD}=1.003)$ and $($ Mean $=2.86, \mathrm{SD}=1.005) ; 3)$ improves the brain activity of youth and aids effective learning $($ Mean $=2.98, \mathrm{SD}=0.226)$ and $(\mathrm{Mean}=$ $2.92, \mathrm{SD}=1.039), 4)$ promotes healthy youths in the society (Mean $=2.87, \mathrm{SD}=0.980$ ) and (Mean $=2.94, \mathrm{SD}=0.972)$, and 5) promotes a wide range of social, physical and intellectual skills of youth $($ Mean $=2.81, \mathrm{SD}=0.965)$ and $($ Mean $=2.98, \mathrm{SD}=0.228)$.

\section{Objective 3: To find out the relationship between music and management of formal education}




\section{Table 4}

Responses on Music

\begin{tabular}{|c|c|c|c|c|c|c|}
\hline \multirow{2}{*}{$\begin{array}{c}\mathrm{S} / \mathrm{N} \\
11\end{array}$} & \multirow{2}{*}{$\begin{array}{l}\text { Music } \\
\text { Music promotes good morals among } \\
\text { youths. }\end{array}$} & \multicolumn{2}{|c|}{$\begin{array}{l}\text { Administrators' } \\
\text { Responses } \\
\text { Mean SD }\end{array}$} & \multicolumn{2}{|c|}{$\begin{array}{l}\text { lecturers' } \\
\text { Responses }\end{array}$} & Decision \\
\hline & & 2.90 & 1.037 & 2.94 & 0.943 & Agreed \\
\hline 12 & $\begin{array}{l}\text { Music improves the activity of the brain } \\
\text { and aids learning. }\end{array}$ & 2.89 & 1.002 & 2.93 & 0.950 & Agreed \\
\hline 13 & $\begin{array}{l}\text { promotion of music in formal education } \\
\text { reduce the rate of drop-out, }\end{array}$ & 3.00 & 0.962 & 2.92 & 0.975 & Agreed \\
\hline 14 & $\begin{array}{l}\text { Educated musicians are good role models } \\
\text { in the society. }\end{array}$ & 2.90 & 1.009 & 2.91 & 0.975 & Agreed \\
\hline \multirow[t]{2}{*}{15} & $\begin{array}{l}\text { Music help youth to be physically, } \\
\text { mentally and psychologically stable. }\end{array}$ & 2.78 & 0.856 & 2.92 & 0.963 & Agreed \\
\hline & Grand Mean & 2.90 & 0.973 & 2.92 & 0.967 & \\
\hline
\end{tabular}

As shown in Table 4, the overall perception of the administrators and lecturers on the importance of music towards improving effective management of formal education is interpreted as 'Agreed' (Mean $=2.90, \mathrm{SD}=0.973$ ) and (Mean $=2.92, \mathrm{SD}=0.967)$. This shows that the participants agreed that music brings about the effective management of formal education in Nigeria. Furthermore, all the responses obtained mean values higher than the criterion mean value of 2.50. This shows that the administrators and lecturers agree that music: 1) promotes good morals among youths (Mean $=2.90, \mathrm{SD}=1.037)$ and $($ Mean $=2.94, \mathrm{SD}=0.943) ; 2$ ) improves the activity of the brain and aids learning (Mean $=2.89, \mathrm{SD}=1.002)$ and $($ Mean $=2.93, \mathrm{SD}=0.950) ; 3$ ) reduces the rate of drop-out $($ Mean $=3.00, \mathrm{SD}=0.962)$ and $($ Mean $=2.92, \mathrm{SD}=0.975) ; 4)$ educated musicians are good role models in the society (Mean $=2.90, \mathrm{SD}=1.009)$ and $(\mathrm{Mean}=$ $2.91, \mathrm{SD}=0.975$ ); and 5) help youth to be physically, mentally and psychologically stable (Mean $=2.78, \mathrm{SD}=0.856)$ and $($ Mean $=2.92, \mathrm{SD}=0.963)$.

\section{Objective 4: To determine the relationship between reality TV shows and management of formal education}


Table 5

Responses on Television Shows

\begin{tabular}{|c|c|c|c|c|c|c|}
\hline \multirow{2}{*}{$\begin{array}{c}\mathrm{S} / \mathrm{N} \\
16\end{array}$} & \multirow{2}{*}{$\begin{array}{l}\text { Reality Television Shows } \\
\text { Reality television show programs } \\
\text { empowering and reduce the problem of } \\
\text { unemployment and poverty among } \\
\text { youth. }\end{array}$} & \multicolumn{2}{|c|}{$\begin{array}{l}\text { Administrators' } \\
\text { Responses } \\
\text { Mean SD }\end{array}$} & \multicolumn{2}{|c|}{$\begin{array}{l}\text { lecturers' } \\
\text { Responses }\end{array}$} & Decision \\
\hline & & 2.94 & 0.969 & 2.94 & 0.943 & Agreed \\
\hline 17 & $\begin{array}{l}\text { Reality tv shows help youths to have } \\
\text { clear goal orientation towards their } \\
\text { choosing career. }\end{array}$ & 2.91 & 0.968 & 2.91 & 0.975 & Agreed \\
\hline 18 & $\begin{array}{l}\text { Reality tv shows promote cultural- } \\
\text { ideology among youth. }\end{array}$ & 2.92 & 0.968 & 2.92 & 0.962 & Agreed \\
\hline 19 & $\begin{array}{l}\text { Reality tv shows promote emotional, } \\
\text { aesthetic and educational well-being among } \\
\text { youth to contribute meaningfully to the } \\
\text { development of the society. }\end{array}$ & 2.93 & 0.964 & 2.90 & 0.993 & Agreed \\
\hline 20 & $\begin{array}{l}\text { Reality tv shows serve as a pathway to } \\
\text { build individual talent and achievement } \\
\text { of educational goals. }\end{array}$ & 2.96 & 0.959 & 2.93 & 0.950 & Agreed \\
\hline & Grand Mean & 2.93 & 0.966 & 2.92 & 0.967 & \\
\hline
\end{tabular}

As shown in Table 5, the overall perception of the administrators and lecturers on the impact of reality television show programs towards enhancing effective management of formal education is interpreted as 'Agreed' (Mean $=2.93, \mathrm{SD}=0.966$ ) and (Mean $=2.92, \mathrm{SD}=0.967$ ). This shows that the participants agreed that reality television show programs improves effective management of formal education in Nigeria. Furthermore, all the responses obtained mean values higher than the criterion mean value of 2.50. This shows that the administrators and lecturers agreed that reality television show programs: 1) empowers and reduces the problem of unemployment and poverty among youth (Mean $=2.94, \mathrm{SD}=0.969)$ and $($ Mean $=2.94, \mathrm{SD}=$ 0.946); 2) helps youth to have clear goal orientation towards their choosing career (Mean $=2.91$, $\mathrm{SD}=0.968)$ and $($ Mean $=2.91, \mathrm{SD}=0.975) ; 3)$ promotes cultural-ideology among youth (Mean $=2.92, \mathrm{SD}=0.968)$ and (Mean $=2.92, \mathrm{SD}=0.962), 4)$ promotes emotional, aesthetic and educational well-being among youth to contribute meaningfully to the development of the society (Mean $=2.93$, SD $=0.964)$ and $($ Mean $=2.90, \mathrm{SD}=0.993)$; and 5) serves as a pathway to build individual talent and achievement of educational goals (Mean $=2.96, \mathrm{SD}=0.959)$ and $($ Mean $=2.93, \mathrm{SD}=0.950)$. 


\section{Hypotheses Testing}

There are four hypotheses set to guide the conduct of this study. Independent T-test was used to test the hypothesis at 0.05 level of significance.

Ho1: There is no significant difference between the mean scores of administrators and lecturers on personality development and management of formal education

\section{Table 6}

Personality Development and Management of Formal Education

\begin{tabular}{llrlllll}
\hline Variable & $\mathbf{N}$ & $\overline{\mathbf{x}}$ & SD & Df & Tcal & t-crit & Decision \\
\hline Administrators & 06 & 2.89 & 0.954 & & & & \\
& & & & 43 & 0.80 & 1.96 & Accepted \\
Lecturers & 39 & 2.87 & 0.997 & & & & \\
\hline
\end{tabular}

Table 6 indicates the t-test analysis between the mean scores of administrators' and lecturers' responses on personality development and management of formal education. The tcalculated value of 0.80 is less than t-critical value of 1.96 . This means there is no significant difference between the responses of administrators and lecturers on personality development and management of formal education. Therefore, the hypothesis which states that there is no significant difference between personality development and management of formal education is accepted.

Ho2: There is no significant difference between the mean scores of administrators and lecturers on sports and management of formal education

\section{Table 7}

Sports and Management of Formal Education

\begin{tabular}{llrlllll}
\hline Variable & $\mathbf{N}$ & $\overline{\mathbf{x}}$ & SD & Df & Tcal & t-crit & Decision \\
\hline Administrators & 06 & 2.86 & 0.838 & & & & \\
Lecturers & 39 & 2.92 & 0.847 & & & & Accepted \\
\hline
\end{tabular}


Table 7 indicates the t-test analysis between the mean scores of administrators' and lecturers' responses on spots and management of formal education. The t-calculated value of 1.22 is less than t-critical value of 1.96. This means there is no significant difference between the responses of administrators and lecturers on sports and management of formal education. Therefore, the hypothesis which states that there is no significant difference between sports and management of formal education is accepted.

Ho2: There is no significant difference between the mean scores of administrators and lecturers on music and management of formal education

\section{Table 8}

Music and Management of Formal Education

\begin{tabular}{llrlllll}
\hline Variable & $\mathbf{N}$ & $\overline{\mathbf{x}}$ & SD & Df & Tcal & t-crit & Decision \\
\hline Administrators & 06 & 2.90 & 0.973 & & & & \\
Lecturers & 39 & 2.92 & 0.969 & & & & Accepted \\
\hline
\end{tabular}

Table 8 indicates the t-test analysis between the mean scores of administrators' and lecturers' responses on music and management of formal education. The t-calculated value of 0.82 is less than t-critical value of 1.96. This means there is no significant difference between the responses of administrators and lecturers on music and management of formal education. Therefore, the hypothesis which states that there is no significant difference between music and management of formal education is accepted.

Ho2: There is no significant difference between the mean scores of administrators and lecturers on reality television show programs and management of formal education

Table 9

Sports and Management of Formal Education

\begin{tabular}{lrrrrrrr}
\hline Variable & $\mathbf{N}$ & $\overline{\mathbf{x}}$ & SD & Df & Tcal & t-crit & Decision \\
\hline Administrators & 06 & 2.93 & 0.966 & & & & \\
Lecturers & 39 & 2.92 & 0.967 & & & & Accepted \\
\hline
\end{tabular}


Table 9 indicates the t-test analysis between the mean scores of administrators' and lecturers' responses on reality television show programs and management of formal education. The $t$-calculated value of 0.53 is less than t-critical value of 1.96. This means there is no significant difference between the responses of administrators and lecturers on reality television show programs and management of formal education. Therefore, the hypothesis which states that there is no significant difference between reality television show programs and management of formal education is accepted.

\section{Discussion of Findings}

The findings in Table 2 shows that personality development enhances the effective management of formal education in Nigeria, such that it shapes the behaviour of individuals and improves the educational success of youth. Fashion programs and various cultural events like Valentine's day, Friendship day, and Mothers' day improves undergraduate's education, promotes the good morale of youth and contributes to social dominance among youth. Results from Hypothesis One revealed that there is no significant difference between personality development and management of formal education in Nigeria. This finding agreed with Vaeyens, Gullich, Warr and Philippaerts (2009) that personality development improves the cognitive skills of youth. This finding also conformed to Roberts, Kuncel, Shiner, Caspi and Goldberg (2007) study that personality development influences the academic performance of students toward achieving educational goals and objectives.

The findings in Table 3 shows that sports improve the effective management of formal education in Nigeria in that it improves youth education and improves the brain activity of youth and aids effective learning. It also promotes healthy youth in society as in addition, promotes a wide range of social, physical and intellectual skills of youth. Results from Hypothesis Two revealed that there was no significant difference between sports and management of formal education in Nigeria. This finding conforms to Eccles, Barbar, Stone and Hunt's study (2003) that athletic activities promote a wide range of social, physical and intellectual skills which lead to better classroom performance. This finding disagreed with Marsh and Kleitman (2002) that involvement of youth in athletes reduce their academic achievement.

The findings in Table 4 shows that music brings about effective management of formal education in Nigeria, such that it promotes good morals among youths, improves the activity of the brain and aids learning, reduces the rate of drop-out, and helps youth to be physically, mentally and psychologically stable. Results from Hypothesis Three revealed that there was no significant difference between music and management of formal education in Nigeria. This finding agreed with Adeola and Isaac (2018) that music arouses the mental, emotional and psychological stability of youth.

The findings in Table 5 shows that reality television show program enhance effective management of formal education in Nigeria, such that it empowers and reduces the problem of unemployment and poverty among youth, it helps youths to have a clear goal orientation towards career choice, and it promotes a cultural-ideology among youth. It also promotes emotional, aesthetic, and educational well-being among youth to contribute meaningfully to the development 
of society as well as serve as a pathway to build individual talent and achievement of educational goals. Results from Hypothesis Four revealed that there was no significant difference between reality television show program and management of formal education in Nigeria. This finding agreed with (Bartsch, 2012; Nielsen, 2009 \& Roe, 2000) that reality television shows shape the behaviour of youth in having a clear goal orientation as to how to deal with various types of relationships. By contrast, this finding disagreed with Gunjan (2016) that reality television programs have ultimately led to deterioration in the social and moral value of youth.

\section{Implications and Conclusion}

The findings of this study will be of great benefit to government, school administrators and stakeholders in education. The findings of this study will help the government and stakeholders in education to understand the importance of talent development promotion as a way of promoting the effective management of formal education. Also, this study would serve as a useful guide and reference point for further researchers in the field of education.

Talent promotion program are important components in ensuring the effective management of formal education towards achieving educational goals and objectives. Based on the findings of this study, the researchers concluded that there was no significant differences between the talent development promotion and management of formal education as they were found to correlate with one another.

\section{Recommendations}

The government should promote the personality development of youth by upgrading the monetary value given to high achievers in school after completion of their program or degree in order to spur more interest and appreciation for education in shaping the behaviour of individuals, improve educational success of youth, improve undergraduate's education, promote good moral of youth, as well as contribute to the social dominance among youth. A government should also provide sports-academic scholarship schemes that will serve as criteria and support for talented youth. This would assist them in pursuing their dreams. It would also ensure that all citizens are catered for educationally so as to enhance the effective management of formal education, improve youth education, and improve the brain activity of youth (which aids effective learning). It would also promote healthy youth in society and promote a wide range of social, physical and intellectual skills of youth. Furthermore, a government should also place more emphasis on music as a way of bringing about a better life for youth so as to promote good morals among them, improve the activity of the brain (which aids learning), reduces the rate of drop-out as well as help youth to be physically, mentally and psychologically stable. In addition, a government should ensure the effective regulation of television programs to be educative, meaningful and relevant to the progress of youth in order to empower and reduce the problem of unemployment and poverty. A government should also help youth to have a clear goal orientation towards their career choice, promote a cultural-ideology among youth, promote emotional, aesthetic and educational wellbeing among youth to contribute meaningfully to the development of society as well as serve as a pathway to build individual talent and achievement of educational goals. 


\section{References}

Abbott, A., \& Collins, D. (2004). Eliminating the dichotomy between theory and practice in talent identification and development: Considering the role of psychology. Journal of Sports Sciences, 22, 395-408. Doi:10.1080/02640410410001675324.

Adeola F. O. and Isaac Y. A (2018), Social Transformation of Africa through Music: The Nigerian Experience. Journal of Educational and Social Research, 8(2), 23-34.

Ary, D. Jacobs, L. C., Irvine, C. K. S. \& Walker, D. (2018). Introduction to research in education. Cengage Learning.

Baker, J., \& Schorer, J. (2010). Identification and development of talent in sport: Introduction to the special issue. Talent Development and Excellence, 2, 119-121.

Bartsch, A. (2012). As time goes by: What changes and what remains the same in entertainment experience over the life span? Journal of Communication, 62(4), 34-42.

Bond, T. G. \& Fox, C. M. (2015). Applying the Research Model Fundamental Measurement in the Human Sciences ( $3^{\text {rd }}$ Ed.). New York \& London: Routledge.

Brannen, J. (2017). Mixing methods: Qualitative and quantitative research. Retrieved from https://www.taylorfrancis.com/books/9781351917186.

Creswell, J. W., \& Creswell, J. D. (2017), Research design: Qualitative, and mixed methods approaches. USA: Sage Publications.

Darling, N., Caldwell, L.L., and Smith, R. (2005). Participation in School-Based Extracurricular Activities and Adolescent Adjustment. Journal of Leisure Research, 37(1), 51-56.

Duckworth, A \& Seligman, M. (2005). Self-discipline outdoes in predicting academic performance of adolescents. Psychological Science, 16, 939-944.

Eccles, J. S., Barber, B. L., Stone, M., \& Hunt, J. (2003). Student extracurricular activities and adolescent development. Journal of Social Issues, 59(4), 865-889.

Geoff Colvin (2010), Talent is overrated "What Really Separates World Class Performers from Everybody Else. Penguin Books Ltd, Registered Offices: 8o Strand, London WC2R ORL, England

Griffin, E. (2008). A first look at communication theory (7th Ed.). New York, Ny: Mcgraw -Hill Higher Education.

Gunjan, S. (2016). Impact of reality tv programs on home science college girls. International

Journal of Educational Research Studies, 2(9), 701-705.

Heckman, J. J., Pinto, R., And Savelyev, P. (2013). Understanding the mechanisms through which an influential early childhood program boosted adult outcomes. American Economic Review, 103(6), 52-86.

L'engle, K. L., Brown, J. D., Kenneavy, K. (2006). The mass media are an important context for adolescent behaviour. Journal of Adolescent Health 38, 186-192.

Leone, R. (2006). Reality television and third-person perception. Journal of Broadcasting Electronic Media, 50(2), 253-269.

Marsh, H. W., \& Kleitman, S. (2002). Extracurricular school activities: The good, the bad and the non-linear. Harvard Educational Review, 72(4), 464-514.

Mereni, A.V. E. (2007). Nigerian/African Musicology in the Global Context. A Paper Presented at the National Conference of the Association of Nigerian Musicologists Held at the Delta State University, Abraka. 2007. 
Nielsen. (2009). Report on television. New York, Ny: Nielsen Media Research.

Onikoyi, O. (2009). Nigerian music: Between the oldies and the contemporaries. retrieved from www.nigerianvillagesquare.Com/the-arts/nigerian-music August 6, 2017.

Papacharissi, Z. \& Mendelsen, A. (2007). An exploratory study of reality appeal: uses and gratifications of reality tv shows. Journal of Broadcasting and Electronic Media, 355 -368 .

Parkinson, M. (2002), How to master personality questionnaires, London: Kogan Page.

Piatek, R. And Pinger, P. (2010). Maintaining Locus of Control: Assessing the Impact of Locus of Control on Education Decisions and Wages. Iza Discussion Papers 5289, Institute for The Study of Labor (Iza).

Punch, K. F. (2005). Introduction to social research. Quantitative and qualitative approaches. London SAGE Publication Ltd.

Roberts, B. W., Kuncel, N., Shiner, R., N., Caspi, A., \& Goldberg, L. R. (2007). The power of personality: The comparative validity of personality traits, socio-economic status, and cognitive ability for predicting important life outcomes. Perspectives in Psychological Science, 2, 313-345.

Roe, K. (2000). Adolescents media use: A European view. Journal of Adolescent Health, 27(2), 15-21. Doi:10.1016/S1054-139x(00)00140-3

Tranckle, P. (2004). Understanding Giftedness and Talent in Sport. The Coach, 21, 61-73.

Vaeyens, R., Lenoir, M., Williams, A. M., \& Philippaerts, R. M. (2008). Talent identification and development programs in sport: current models and future directions. Sports

Medicine, 38, 703-714.

Vaeyens, R., Gullich, A., Warr, C. R., \& Philippaerts, R. (2009). Talent identification and promotion programs of Olympic athletes. Journal of Sports Sciences, 27, 1367-1380. Doi: $10.1080 / 02640410903110974$

Williams, A. M., \& Reilly, T. (2000). Talent identification and development in soccer. Journal of Sports Sciences, 18, 657-667. Doi:10.1080/02640410050120041

Wolstencroft, E. (Ed.). (2002). Talent identification and development: An Academic Review. Edinburgh, United Kingdom: Sport Scotland. 